\title{
Rapid volume loss from two East Greenland outlet glaciers quantified using repeat stereo satellite imagery
}

\author{
Leigh A. Stearns ${ }^{1}$ and Gordon S. Hamilton ${ }^{1}$ \\ Received 12 December 2006; revised 14 January 2007; accepted 7 February 2007; published 14 March 2007.
}

[1] The coastal portions of Kangerdlugssuaq and Helheim glaciers in southeast Greenland lost at least $51 \pm 8 \mathrm{~km}^{3} \mathrm{yr}^{-1}$ of ice between 2001-2006 due to thinning and retreat, according to an analysis of sequential digital elevation models (DEMs) derived from stereo ASTER satellite imagery. The dominant contribution to this ice loss was dynamic thinning caused by the acceleration in flow of both glaciers. Peak rates of change, including thinning rates of $\sim 90 \mathrm{~m} \mathrm{yr}^{-1}$, coincided with the rapid increases in flow speed. Extrapolation of the measured data to the ice divides yields an estimated combined catchment volume loss of $\sim 122 \pm 30 \mathrm{~km}^{3} \mathrm{yr}^{-1}$, which accounts for half the total mass loss from the ice sheet reported in recent studies. These catchment-wide volume losses contributed $\sim 0.31 \pm$ $0.07 \mathrm{~mm} \mathrm{yr}^{-1}$ to global sea level rise over the 5-year observation period with the coastal regions alone contributing at least $0.1 \pm 0.02 \mathrm{~mm} \mathrm{yr}^{-1}$. Citation: Stearns, L. A., and G. S. Hamilton (2007), Rapid volume loss from two East Greenland outlet glaciers quantified using repeat stereo satellite imagery, Geophys. Res. Lett., 34, L05503, doi:10.1029/2006GL028982.

\section{Introduction}

[2] The Greenland Ice Sheet's contribution to sea level more than doubled in the past decade, from $0.23 \mathrm{~mm} \mathrm{yr}^{-1}$ in 1996 to $0.57 \mathrm{~mm} \mathrm{yr}^{-1}$ in 2005 [Rignot and Kanagaratnam, 2006]. Several large outlet glaciers accelerated during this same period [Howat et al., 2005; Rignot and Kanagaratnam, 2006]. There is no evidence that snow accumulation increased sufficiently to compensate for the enhanced discharge of mass [Velicogna and Wahr, 2006], inferring that ice dynamics are playing a major role in Greenland's sea level contribution.

[3] The largest changes in ice dynamics are observed in southeast Greenland. Kangerdlugssuaq Glacier $\left(68.5^{\circ} \mathrm{N}\right.$, $33^{\circ} \mathrm{W}$ ) accelerated from $5 \mathrm{~km} \mathrm{yr}^{-1}$ to $14 \mathrm{~km} \mathrm{yr}^{-1}$ in the past 4 years [Rignot and Kanagaratnam, 2006], with most of the acceleration taking place between 2004-2005 [Luckman et al., 2006]. Helheim Glacier $\left(66.5^{\circ} \mathrm{N}, 38^{\circ} \mathrm{W}\right)$ accelerated from $6 \mathrm{~km} \mathrm{yr}^{-1}$ to $11 \mathrm{~km} \mathrm{yr}^{-1}$ between 2002 and 2005 [Howat et al., 2005; Luckman et al., 2006]. Similar changes are apparently widespread on Greenland outlet glaciers south of $\sim 70^{\circ}$ [Rignot and Kanagaratnam, 2006], but less evident farther north [Stearns et al., 2005].

[4] Flow acceleration leads to dynamic thinning by increasing longitudinal stretching rates. Several Greenland outlet glaciers have been thinning at rates of $1-10 \mathrm{~m} \mathrm{yr}^{-1}$ since the mid-1990s [Abdalati et al., 2001; Thomas et al.,

\footnotetext{
${ }^{1}$ Climate Change Institute, University of Maine, Orono, Maine, USA.
}

$2000,2006]$, perhaps as a result of this process. We observed unweathered ice stranded on fjord walls approximately $100 \mathrm{~m}$ above the present surfaces of Kangerdlugssuaq and Helheim glaciers during field visits in July 2005, indicating a relatively recent drawdown and a possible increase in the rates of glacier thinning. Here we quantify rates and timings of surface elevation and ice volume change on both glaciers for the period 2001-2006 using repeat stereo satellite images.

\section{DEM Extraction Method and Errors}

[5] The ASTER sensor (Advanced Spaceborne Thermal Emission and Reflection Radiometer) collects a stereo image-pair using two telescopes in visible band 3: a nadirviewing telescope $(3 \mathrm{~N})$ and a backward-looking telescope (3B) [Yamaguchi et al., 1998]. The advantage of using the ASTER instrument for stereo mapping over other sensors such as SPOT1-5 [Berthier et al., 2004] is that the overlapping nadir and backward images are collected at nearly the same time (57 s apart) on the same orbit cycle, minimizing the impacts of image decorrelation.

[6] We generate digital elevation models (DEMs) in-house from stereo imagery of Kangerdlugssuaq and Helheim glaciers using the Japanese ASTER Science Team procedure described by Fujisada et al. [2005]. Products generated using identical procedures can be ordered from the NASA/USGS Land Processes Distributed Active Archive Center (LPDAAC) at http://edcimswww.cr.usgs. gov/pub/imswelcome. Suitable images were selected on the basis of minimal cloud cover and small off-nadir image acquisition angles (ASTER can acquire images up to $\pm 24^{\circ}$ from nadir in the across-track direction). The images used in this study were collected during summer months (June through August), to minimize the effects of seasonal variations on surface elevation (dates and image IDs are listed in Table $\mathrm{S} 1$ of the auxiliary material). ${ }^{1}$ The $3 \mathrm{~N}$ and $3 \mathrm{~B}$ scenes are co-registered using a cross-correlation algorithm which matches brightness values between scenes, and elevation information is extracted using the parallax formed from each stereo pair. To prevent the occurrence of false elevation changes, we manually edit obvious blunders and semiautomatically mask clouds from the processed data.

[7] Each DEM has a post spacing of $15 \mathrm{~m}$, corresponding to the pixel resolution of ASTER's visible bands. Geolocation is entirely on the basis of the satellite ephemeris information contained in the image header file and has an uncertainty of approximately $50 \mathrm{~m}$, which is consistent with the error in spacecraft positioning [Fujisada et al.,

\footnotetext{
${ }^{1}$ Auxiliary materials are available at $\mathrm{ftp} / / / \mathrm{ftp}$.agu.org/apend/gl/ $2006 \mathrm{~g} 1028982$.
} 

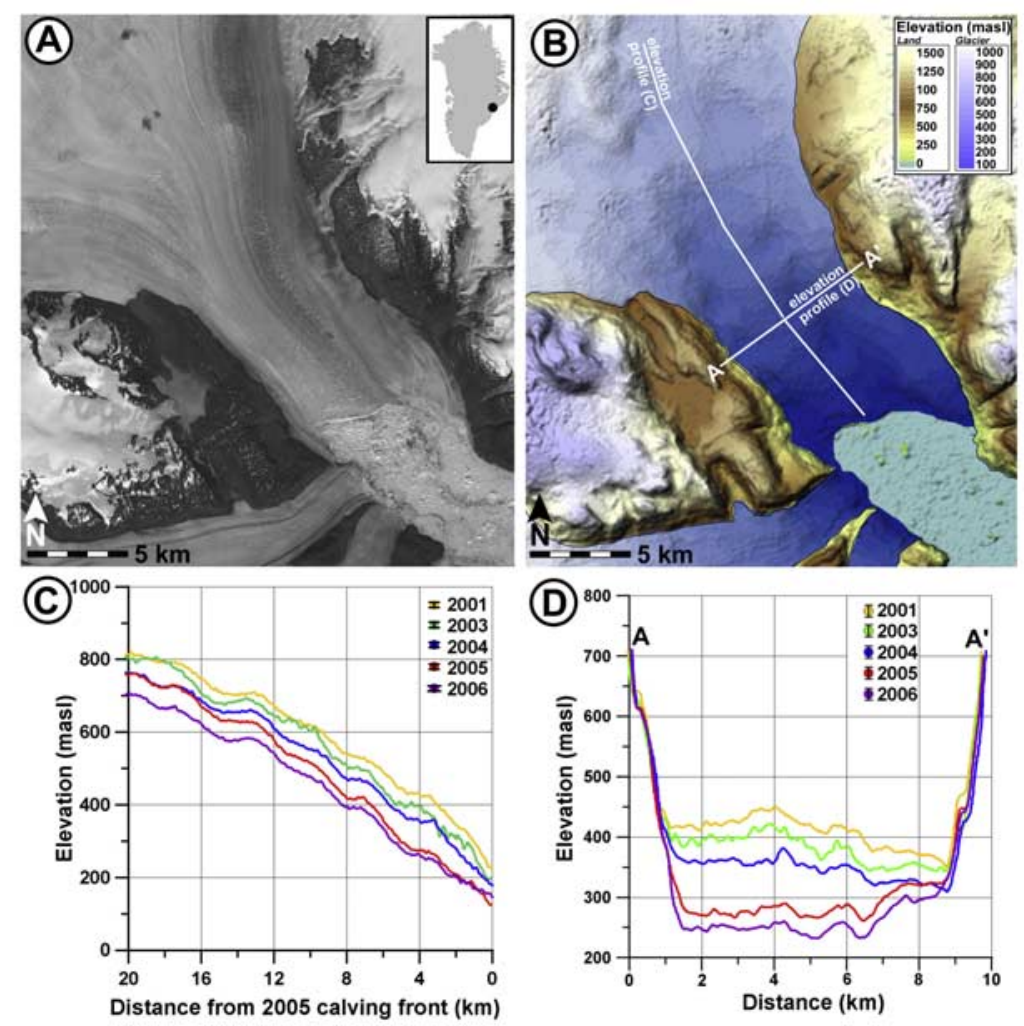

Figure 1. Kangerdlugssuaq Glacier $\left(68.5^{\circ} \mathrm{N}, 33^{\circ} \mathrm{W}\right)$. (a) ASTER image acquired June 21, 2005. (b) Surface topography derived from the image in Figure 1a. (c) Surface elevation change on the along-flow profile labeled in Figure $1 \mathrm{~b}(0 \mathrm{~km}$ is the 2005 terminus position). (d) Surface elevation change on the across-flow elevation profile labeled in Figure $1 \mathrm{~b}$. Note the consistent elevation profiles on the steep fjord walls on either side of the glacier, indicating the good quality of the sequential DEMs.

2005]. We minimize the effect of geolocation errors in the subsequent analysis by manually co-registering sequential DEMs.

[8] The DEM uncertainties are a combination of systematic errors, or bias, and random errors due to satellite positioning, image acquisition geometry, and atmospheric conditions. We did not detect any bias in a pair-wise comparison of elevations of static points extracted from $5 \times 5 \mathrm{~km}$ bedrock sections in each DEM, as shown by an arithmetic mean elevation difference of $-3 \mathrm{~m}$ for all pairs. The random errors contribute a root mean square error in elevation of $\pm 7.1 \mathrm{~m}$ for all image pairs, based on a comparison of the elevation differences of the static areas. This error is consistent with uncertainties of $\sim 5-10 \mathrm{~m}$ reported by Fujisada et al. [2005]. In the following sections describing thinning and volume change calculations, we assume a conservative elevation uncertainty of $\pm 10 \mathrm{~m}$ to account for additional possible errors due to DEM extraction over high-elevation parts of each glacier where there is no static ground control.

\section{Observed Changes}

\subsection{Surface Elevation}

[9] For Kangerdlugssuaq Glacier (Figure 1a), changes in surface elevation were computed for two profiles along and across the glacier (Figure 1b). Between 2001-2004, thinning rates were nearly uniform $\left(20 \pm 5 \mathrm{~m} \mathrm{yr}^{-1}\right)$ along the $20 \mathrm{~km}$ profile to the 2005 calving front (Figure 1c). The front thinned faster $\left(87 \pm 14 \mathrm{~m} \mathrm{yr}^{-1}\right)$ than the upper glacier (12 $\pm 15 \mathrm{~m} \mathrm{yr}^{-1}$ ) between 2004-2005 (Figure 1c), coinciding with flow speed acceleration and rapid retreat of the calving front (L. A. Stearns and G. S. Hamilton, manuscript in preparation, 2007). Between 2005-2006, thinning rates were larger $\left(59 \pm 13 \mathrm{~m} \mathrm{yr}^{-1}\right)$ in the upper glacier compared to the terminus region $\left(28 \pm 13 \mathrm{~m} \mathrm{yr}^{-1}\right)$, indicating that changes initiated near the front had propagated $\sim 20 \mathrm{~km}$ upglacier in one year. Thinning extended across the whole width of the glacier near the calving front, as shown by the cross-profile (Figure 1d), but was concentrated on the eastern half of the glacier. Here, thinning rates were $20 \pm 5 \mathrm{~m} \mathrm{yr}^{-1}$ between 2001-2004. This rate increased to $87 \pm 14 \mathrm{~m} \mathrm{yr}^{-1}$ between 2004-2005 (Figure 1d) but slowed to $28 \pm 13 \mathrm{~m} \mathrm{yr}^{-1}$ between $2005-$ 2006. Note that in all cases the quoted errors appear relatively large because we adopt a conservative uncertainty $(10 \mathrm{~m})$ in elevation determination.

[10] Widespread thinning is also detected on Helheim Glacier (Figure 2a). Two profiles along and across the glacier (Figure 2b) show that thinning occurred in two episodes. The first episode between 2002-2003 resulted in a mean thinning rate of $44 \pm 21 \mathrm{~m} \mathrm{yr}^{-1}$ on the $20 \mathrm{~km}$ longitudinal profile to the 2005 calving front (Figure 2c). Slower thinning rates $\left(15 \pm 21 \mathrm{~m} \mathrm{yr}^{-1}\right)$ occurred between 2003-2004. The thinning accelerated to $60 \pm 13 \mathrm{~m} \mathrm{yr}^{-1}$ between 2004-2005, and decreased again between 20052006 (to $7 \pm 21 \mathrm{~m} \mathrm{yr}^{-1}$ ). Similar patterns and rates of 

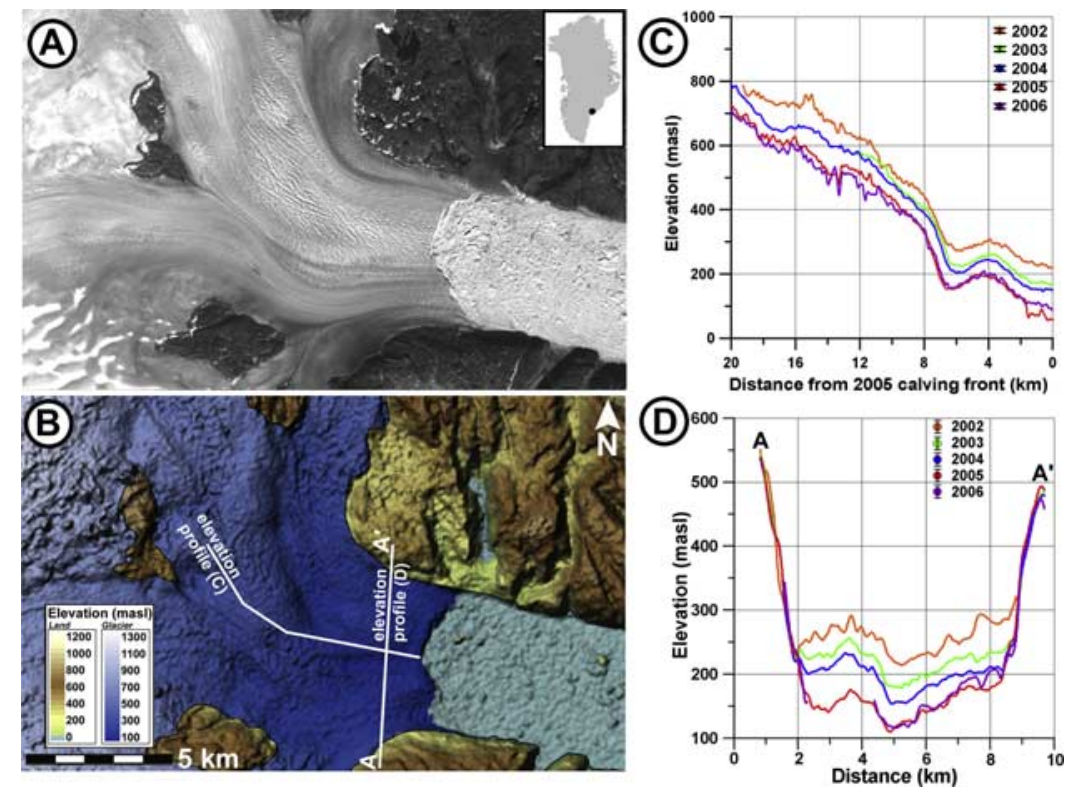

Figure 2. Helheim Glacier $\left(66.5^{\circ} \mathrm{N}, 38^{\circ} \mathrm{W}\right)$. (a) ASTER image acquired August 29,2005 . (b) Surface topography derived from the image in Figure 2a. (c) Surface elevation change on the along-flow elevation profile labeled in Figure $2 \mathrm{~b}(0 \mathrm{~km}$ is the terminus). (d) Surface elevation change on the across-flow elevation profile labeled in Figure $2 \mathrm{~b}$.

surface lowering are measured on a transverse profile near the 2005 calving front (Figure 2d).

[11] These thinning rates are much larger than elevation changes measured along repeat laser altimeter flight-lines on the same glaciers. Abdalati et al. [2001] report thinning rates near the calving fronts of $\sim 2-10 \mathrm{~m} \mathrm{yr}^{-1}$ in the late 1990s, and Krabill et al. [2004] note continued thinning in excess of $3 \mathrm{~m} \mathrm{yr}^{-1}$ between 1997-2003. Both studies detected smaller but still significant amounts of thinning up to $70 \mathrm{~km}$ inland from the calving fronts, which is consistent with the pattern derived from our repeat DEM analysis. We attribute the overall difference in thinning rates to a switch from gradual thinning in the 1990s to rapid thinning since 2000 .

\subsection{Volume}

[12] By producing DEMs for two different years and differencing them, we are able to derive estimates of volume change across extensive regions within $\sim 50 \mathrm{~km}$ of the coast on both glaciers. Images to cover this larger region are available only for 2001 and 2006 for Kangerdlugssuaq Glacier, and 2002 and 2005 for Helheim Glacier (nearlyannual DEM coverage is available for the lower portions of each glacier). Our analysis shows that Kangerdlugssuaq Glacier lost $\sim 119 \pm 17 \mathrm{~km}^{3}$ of ice from thinning within a $1,750 \mathrm{~km}^{2}$ region (Figure $3 \mathrm{a}$ ) over the period of observation. The retreat of the calving front contributed an additional volume loss which we estimate to be $\sim 19 \mathrm{~km}^{3}$, based on a frontal ice thickness of $700 \mathrm{~m}$ [Thomas et al., 2000]. A 1,040 $\mathrm{km}^{2}$ region of Helheim Glacier (Figure 3b) lost $\sim 52 \pm 9 \mathrm{~km}^{3}$ between 2002 and 2005, with an additional $\sim 18 \mathrm{~km}^{3}$ of ice loss being attributed to calving front retreat. According to our estimates, the coastal portions of Kangerdlugssuaq and Helheim glaciers lost a combined volume of $\sim 51 \pm 8 \mathrm{~km}^{3}$ $\mathrm{yr}^{-1}$ due to thinning and terminus retreat.

[13] Surface elevation changes measured near the coast are extrapolated to higher elevations using fourth-order polynomials (Figures $3 \mathrm{c}$ and $3 \mathrm{~d}$ ) to estimate catchmentwide volume losses for both glaciers [cf. Arendt et al., 2002; Rignot et al., 2003]. We constrain the polynomial fit at the ice divides with a thickening rate of $0.1 \mathrm{~m} \mathrm{yr}^{-1}$ [Krabill et al., 2004; Thomas et al., 2006; Zwally et al., 2005]. A coarse-resolution DEM [Bamber et al., 2001] is used to determine the catchment dimensions and the surface area of elevation bands for regions above the DEM coverage, binned at $250 \mathrm{~m}$ contour intervals. The mean thinning rate is computed for each bin and multiplied by its surface area, and the results added to the DEM-derived changes to estimate the total catchment volume change. Uncertainties in these estimates are difficult to evaluate for the high elevation regions where independent elevation change data are sparse. As a substitute, we repeat the polynomial analysis using only those regions with DEM coverage and compare the results with the DEM-derived changes. The results differ by $\sim 25 \%$, which we take as the uncertainty in estimated catchment-wide volume changes. The $51,088 \mathrm{~km}^{2}$ catchment basin of Kangerdlugssuaq Glacier lost a total of $\sim 310 \pm 77 \mathrm{~km}^{3}$ between 2001 and 2006, or the equivalent of $62 \pm 15 \mathrm{~km}^{3} \mathrm{yr}^{-1}$. Helheim Glacier, with a catchment of $48,319 \mathrm{~km}^{2}$, lost $\sim 180 \pm 60 \mathrm{~km}^{3}$ between 2002 and 2005 , or the equivalent of $60 \pm 15 \mathrm{~km}^{3} \mathrm{yr}^{-1}$. Note that, due to image availability, the thinning rate for Kangerdlugssuaq Glacier is a 5-year average, whereas for Helheim Glacier it is a 3 -year average.

[14] These volume loss estimates represent a significant fraction of the total volume loss from the ice sheet. Estimates of mass loss using GRACE satellite gravity data range from 101-129 $\mathrm{km}^{3} \mathrm{yr}^{-1}$ [Luthcke et al., 2006; Ramillien et al., 2006] to $239-248 \mathrm{~km}^{3} \mathrm{yr}^{-1}$ [Chen et al., 2006; Velicogna and Wahr, 2006] for varying periods between 2002-2006. All studies reveal similar patterns of mass loss in southeast Greenland. Velicogna and Wahr [2006] attribute $161 \pm 24 \mathrm{~km}^{3} \mathrm{yr}^{-1}$ to glaciers in south 

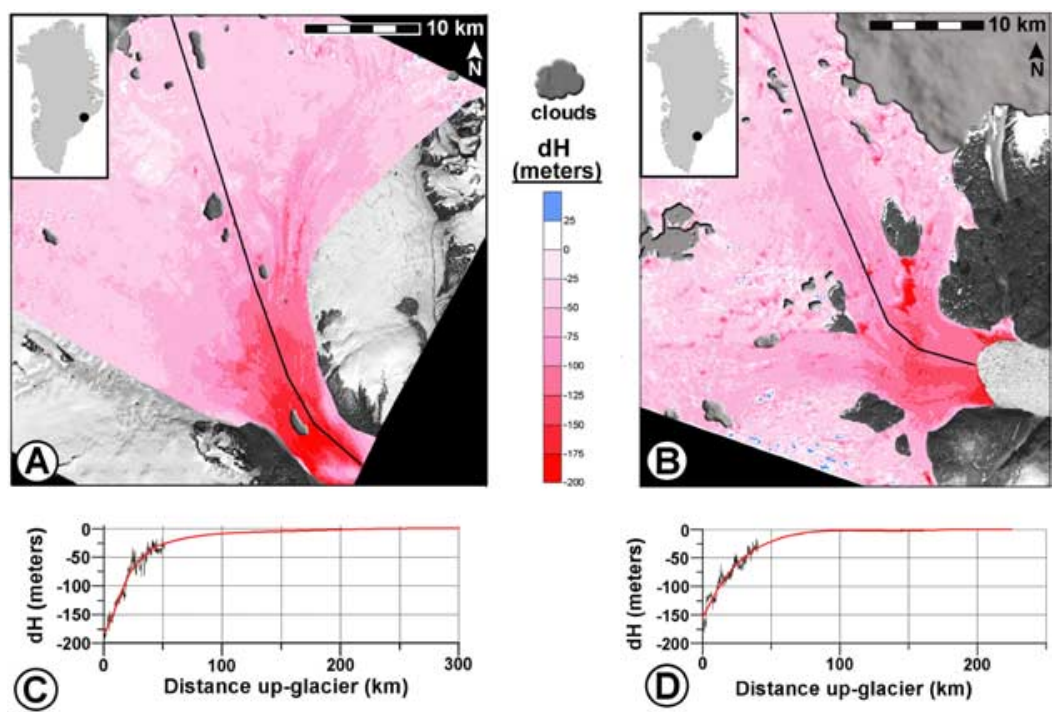

Figure 3. (a) Map of surface elevation change on Kangerdlugssuaq Glacier, over a $1,750 \mathrm{~km}^{2}$ area between July $2001-$ July 2006. (b) Map of surface elevation change on Helheim Glacier over a $1,040 \mathrm{~km}^{2}$ area between June $2002-$ August 2005. (c) Fourth-order polynomial fitted to measured surface elevation changes on Kangerdlugssuaq Glacier and extrapolated to the ice divide along the black line in Figure 3a. (d) Fourth-order polynomial fitted to measured surface elevation changes on Helheim Glacier and extrapolated to the ice divide along the black line in Figure $3 \mathrm{~b}$.

Greenland; our estimate from just two of these southeastern glaciers is $\sim 122 \pm 30 \mathrm{~km}^{3} \mathrm{yr}^{-1}$ for a nearly-similar time period. While these estimates are close, part of the difference might be a function of the inability to discriminate in the footprint of the GRACE data which glaciers are losing mass. A more straightforward comparison can be made between our results and estimates provided by Rignot and Kanagaratnam [2006] based on flux calculations. Their reported volume losses for Kangerdlugssuaq and Helheim glaciers $\left(\sim 36 \mathrm{~km}^{3} \mathrm{yr}^{-1}\right.$ and $\sim 12 \mathrm{~km}^{3} \mathrm{yr}^{-1}$ respectively) are significantly smaller than our catchment-wide estimates, although close to our estimates for losses in the coastal regions. One explanation for the discrepancy is an overestimate of catchment accumulation rate in the flux calculations which would have the effect of reducing the net difference between the outgoing flux and the mass input. An alternative explanation is that our extrapolation of coastal results to the ice divide leads to erroneous thinning in parts of the upper catchment that are gaining mass.

\section{Interpretation}

[15] The measured thinning rates of several tens of $\mathrm{m} \mathrm{yr}^{-1}$ far exceed what might reasonably be expected from enhanced surface melting alone. A substantial amount of the thinning and volume losses must be due to an increase in longitudinal stretching rates caused by the changes in ice dynamics.

[16] The continuity equation

$$
\frac{\partial H}{\partial t}+\nabla \cdot \mathbf{H U}+\dot{b}=0,
$$

defines the width-averaged rate of thickness change $\partial \mathrm{H} / \partial t$ as a function of the gradient in ice velocity $U$ and the net surface balance $\dot{b}$. We make the simplification that the glacier width is constant, which is a reasonable assumption for the studied sections. Averaged cross-sectional ice velocities come from measurements on summertime satellite image pairs (L. A. Stearns and G. S. Hamilton, manuscript in preparation, 2007). For the case of fast flowing glaciers, the flux terms dominate the surface balance terms, so we omit $\dot{b}$ from our analysis. Values of $H$ are available from ice-penetrating radar surveys along the centerlines of both glaciers [Abdalati et al., 2001; Thomas et al., 2000], but are missing for regions within a few $\mathrm{km}$ of the calving fronts and in the across-flow direction. We estimate ice thicknesses at the front using DEM-derived calving face heights and hydrostatic equilibrium, assuming floating tongues. We scale the computed fluxes by a shape factor of 0.75 to account for unknown across-flow variations in $H$. Both of these estimates are subject to errors which are difficult to quantify without additional radar surveys, although their effect on the calculated fluxes are unlikely to alter the sense of the solutions to equation (1), at least to first-order.

[17] We evaluate equation (1) for the lower sections of each glacier using the values in Table 1 . The calculations yield a total 4-year (2001-2005) thinning due to ice dynamics of $\sim 212 \mathrm{~m}$ for Kangerdlugssuaq Glacier, and $\sim 130 \mathrm{~m}$ for Helheim Glacier. These estimates are consistent with thinning amounts derived from the repeat DEM analysis (Figures 1d and 2d). Small differences between the calculated and measured values are to be expected because of assumptions about ice thickness and omission of the surface balance terms, and because of likely transient speed variations not captured in the velocity data. Rignot and Kanagaratnam [2006] calculate a similar amount of dynamic thinning for Kangerdlugssuaq Glacier $(\sim 250 \mathrm{~m})$, but a slightly smaller amount for Helheim Glacier $(\sim 75 \mathrm{~m})$ perhaps because of differences in assumed ice thickness. The overall good agreement between the observations and the amounts of calculated thinning indicates that the recent 
Table 1. Quantities Used to Solve Equation (1) ${ }^{\mathrm{a}}$

\begin{tabular}{|c|c|c|}
\hline Kangerdlugssuaq & & Helheim \\
\hline$H \sim 600 \mathrm{~m}, H^{\prime} \sim 700 \mathrm{~m}$ & & $H \sim 850 \mathrm{~m}, H^{\prime} \sim 700 \mathrm{~m}$ \\
\hline$U-U^{\prime} \sim 2.3 \mathrm{~km} \mathrm{yr}^{-1}-\sim 3.9 \mathrm{~km} \mathrm{yr}^{-1}$ & 2001 & $U-U^{\prime} \sim 4.5 \mathrm{~km} \mathrm{yr}^{-1}-\sim 5.5 \mathrm{~km} \mathrm{yr}^{-1}$ \\
\hline$\underline{U-U^{\prime} \sim 7.1 \mathrm{~km} \mathrm{yr}^{-1}-\sim 12.6 \mathrm{~km} \mathrm{yr}^{-1}}$ & 2005 & $U-U^{\prime} \sim 6.7 \mathrm{~km} \mathrm{yr}^{-1}-\sim 9.6 \mathrm{~km} \mathrm{yr}^{-1}$ \\
\hline
\end{tabular}

accelerations of Kangerdlugssuaq and Helheim glaciers are driving the rapid volume losses.

\section{Conclusion}

[18] Since 2001, the coastal portions of Helheim and Kangerdlugssuaq glaciers have lost a combined $208 \pm$ $15 \mathrm{~km}^{3}$ of ice by thinning and retreat, or the equivalent of $51 \pm 8 \mathrm{~km}^{3} \mathrm{yr}^{-1}$. Extrapolation of the measured data to the ice divides yields a total combined catchment volume loss of $\sim 122 \pm 30 \mathrm{~km}^{3} \mathrm{yr}^{-1}$. Ice thinning and volume loss rates peaked just after both glaciers underwent rapid flow accelerations, with peak thinning rates reaching $\sim 90 \mathrm{~m} \mathrm{yr}^{-1}$. Increased longitudinal stretching accounts for nearly all the measured thinning, as shown by a volume continuity analysis.

[19] Assuming the density of the volume loss is that of ice $\left(917 \mathrm{~kg} \mathrm{~m}^{-3}\right)$, the five-year average contribution to sea level was $\sim 0.1 \pm 0.02 \mathrm{~mm} \mathrm{yr}^{-1}$ from the coastal portions alone, and $\sim 0.31 \pm 0.07 \mathrm{~mm} \mathrm{yr}^{-1}$ from the catchments as a whole. These estimates, from just two glaciers, are a significant fraction of the total Greenland contribution to sea level rise of $\sim 0.57 \mathrm{~mm} \mathrm{yr}^{-1}$ [Rignot and Kanagaratnam, 2006], and confirm that changes in southeast Greenland are the dominant source of recent accelerations in mass loss from the ice sheet [Velicogna and Wahr, 2006].

[20] In addition to the effect on sea level, we expect the rapid rates of volume loss will have two other important impacts. One is to cause a rapid elastic adjustment of the lithosphere which should be detectable by geodetic methods. The second effect is ongoing changes in the flow dynamics of Kangerdlugssuaq and Helheim glaciers due to changes in glacier geometry, which should be detectable with ongoing monitoring of their flow behavior.

[21] Acknowledgments. We thank Etienne Berthier and two anonymous reviewers for comments which improved this paper. Data analysis was supported by a NASA Earth Systems Science Graduate Fellowship (to LAS), and NNG04-GK39G from NASA's Cryospheric Sciences Program (to GSH).

\section{References}

Abdalati, W., W. Krabill, E. Frederick, S. Manizade, C. Martin, J. Sonntag, R. Swift, R. Thomas, and W. Wright (2001), Outlet glacier and margin elevation changes: Near-coastal thinning of the Greenland ice sheet, J. Geophys. Res., 106, 33,729-33,742.

Arendt, A., K. A. Echelmeyer, W. D. Harrison, C. S. Lingle, and V. B. Valentine (2002), Rapid wastage of Alaska glaciers and their contribution to rising sea level, Science, 297, 382-386.
Bamber, J. L., R. L. Layberry, and S. P. Gogineni (2001), A new ice thickness and bed data set for the Greenland ice sheet: 1. Measurement, data reduction, and errors, J. Geophys. Res., 106, 33,773-33,780.

Berthier, E., Y. Arnaud, D. Baratoux, C. Vincent, and F. Rémy (2004), Recent rapid thinning of the "Mer de Glace" glacier derived from satellite optical images, Geophys. Res. Lett., 31, L17401, doi:10.1029/ 2004GL020706.

Chen, J. L., C. R. Wilson, and B. D. Tapley (2006), Satellite gravity measurements confirm accelerated melting of the Greenland ice sheet, Science, 313, 1958-1960.

Fujisada, H., G. B. Bailey, G. G. Kelly, S. Hara, and M. J. Abrams (2005), ASTER DEM performance, IEEE Trans. Geosci. Remote Sens., 43, $2707-2714$

Howat, I. M., I. Joughin, S. Tulaczyk, and S. Gogineni (2005), Rapid retreat and acceleration of Helheim Glacier, east Greenland, Geophys. Res. Lett., 32, L22502, doi:10.1029/2005GL024737.

Krabill, W., et al. (2004), Greenland ice sheet: Increased coastal thinning, Geophys. Res. Lett., 31, L24402, doi:10.1029/2004GL021533.

Luckman, A., T. Murray, R. de Lange, and E. Hanna (2006), Rapid and synchronous ice-dynamic changes in east Greenland, Geophys. Res. Lett., 33, L03503, doi:10.1029/2005GL025428.

Luthcke, S. B., H. J. Zwally, W. Abdalati, D. D. Rowlands, R. D. Ray, R. S. Nerem, F. G. Lemoine, J. J. McCarthy, and D. S. Chinn (2006), Recent Greenland ice mass loss by drainage system from satellite gravity observations, Science, 314, 1286-1289.

Ramillien, G., A. Lombard, A. Cazenave, E. R. Ivins, M. Llubes, F. Rémy, and R. Biancale (2006), Interannual variations of the mass balance of the Antarctica and Greenland ice sheets from GRACE, Global Planet. Change, 53, 198-208.

Rignot, E. J., and P. Kanagaratnam (2006), Changes in the velocity structure of the Greenland ice sheet, Science, 311, 986-990.

Rignot, E., A. Rivera, and G. Casassa (2003), Contribution of the Patagonia icefields of South America to sea level rise, Science, 302, 434-437.

Stearns, L. A., G. S. Hamilton, and N. Reeh (2005), Multi-decadal record of ice dynamics on Daugaard Jensen Gletscher, east Greenland, from satellite imagery and terrestrial measurements, Ann. Glaciol., 42, 53-58.

Thomas, R. H., W. Abdalati, T. L. Akins, B. M. Csatho, E. B. Frederick, S. P. Gogineni, W. B. Krabill, S. S. Manizade, and E. J. Rignot (2000), Substantial thinning of a major east Greenland outlet glacier, Geophys. Res. Lett., 27, 1291-1294.

Thomas, R., E. Frederick, W. Krabill, S. Manizade, and C. Martin (2006), Progressive increase in ice loss from Greenland, Geophys. Res. Lett., 33, L10503, doi:10.1029/2006GL026075.

Velicogna, I., and J. Wahr (2006), Acceleration of Greenland ice mass loss in spring 2004, Nature, 443, 329-331, doi:10.1038/nature05168.

Yamaguchi, Y., A. B. Kahle, H. Tsu, T. Kawakami, and M. Pniel (1998), Overview of Advanced Spaceborne Thermal Emission and Reflection Radiometer (ASTER), IEEE Trans. Geosci. Remote Sens., 36, 1062-1071.

Zwally, H. J., M. B. Giovinetto, J. Li, H. G. Cornejo, M. A. Beckley, A. C. Brenner, J. L. Saba, and D. Yi (2005), Mass changes of the Greenland and Antarctic ice sheets and shelves and contributions to sea-level rise: 1992-2002, J. Glaciol., 51, 509-527.

G. S. Hamilton and L. A. Stearns, Climate Change Institute, and Department of Earth Sciences, University of Maine, 5790 Bryand Global Sciences Center, Orono, ME 04469-5790, USA. (gordon.hamilton@maine.edu; leigh.stearns@maine.edu) 